811.111'243'342.41:811.113.5

https://doi.org/10.18485/bells.2021.13.3

\author{
Oleksandr Kapranov* \\ NLA University College \\ Oslo, Norway
}

\title{
THE ENGLISH VOWEL SCHWA AS A DIFFICULTY TO INTERMEDIATE EFL STUDENTS: EVIDENCE FROM PHONEMIC TRANSCRIPTION ${ }^{* *}$
}

\begin{abstract}
This article presents a study that seeks to investigate whether or not the English neutral vowel schwa (henceforth - schwa) poses difficulties to a group of intermediate students of English as a Foreign Language (EFL) whose first language is Norwegian (further - participants). The study involves a corpus of phonemic transcriptions written by the participants in the series of 4 tasks. In the corpus, schwa-related errors are identified in accordance with the methodological approach formulated by Mompean and Fouz-González (2021). The results reveal several substitutions of schwa for $/ \mathrm{e} /, / \mathrm{p} /, / \mathfrak{m} /, / \mathrm{a}: /$, and /3:/. These findings correlate with the results of the post-hoc procedure that involves the identification and classification of schwa-related errors in the participants' speech in English. Further, the findings are discussed from the vantage point of schwa as a difficulty to intermediate EFL learners.
\end{abstract}

Key words: English as a Foreign Language (EFL), error analysis, phonemic transcription, schwa

\footnotetext{
E-mail address: oleksandr.kapranov@nla.no

** This paper was presented at the Fifth Belgrade International Meeting of English Phoneticians (BIMEP 2020), 20-21 March 2020, Faculty of Philology, University of Belgrade.
} 


\section{Introduction}

This article presents and discusses a study that seeks to investigate whether or not intermediate students of English as a Foreign Language (EFL) experience difficulties with the English neutral vowel schwa (further in the article - schwa). In the present study, schwa is operationalised as a central unrounded vowel with the neutral lip position that typically occurs in unstressed syllables due to articulatory reduction of peripheral vowels (Čubrović 2007; Flemming 2009; Recasens 2021; Silverman 2011). Schwa is represented in the International Phonetic Alphabet (IPA) as the symbol / $/$ / that is placed in the middle of the IPA vowel chart (Carley and Mees 2021). Due to its frequency and systematicity of use in the English language, schwa is often referred to as a default vowel sound (Boswell 2020). In English, schwa is characterised by a free distribution, i.e. it may occur in initial, medial and final positions in a word (Čubrović 2007). In addition to the unstressed syllables in polysyllabic words, schwa is typically associated with the weak forms (e.g., must /most/) of function words due to the rhythm and intonation in the utterance (Carley and Mees 2021). Schwa is not found in the strong forms (e.g., must /mıst/) of function words that are stressed in the utterance and stressed syllables of the standalone words, for instance dictionary entries (Cruttenden 2014).

From the point of view of diachrony, schwa is associated with different historical processes of sound change in the English language (Minkova and Lefkowitz 2021). In synchrony, the patterning of schwa exhibits a tendency to vary depending on the variety of English (Heselwood 2007). For instance, in the Southern British Standard variety, or SBS (Čubrović and Bjelaković 2020), schwa is widely omitted without affecting the meaning of a word (Demirezen 2021; Heselwood 2006). In contrast to SBS, however, schwa does not appear to be easily omitted in General American (GA). According to Demirezen (2021: 6), this observation can be illustrated by the following pairs of words in SBS and GA, cf. 
Oleksandr Kapranov: The English Vowel Schwa as a Difficulty to Intermediate EFL...

\begin{tabular}{|c|c|c|c|}
\hline $\mathbf{N}$ & Word & $\mathbf{G A}$ & SBS \\
\hline 1 & Military & /'milə,teri/ & /'mulitri/ \\
\hline 2 & Ordinary & /'orrdən, eri/ & /'o:dənri/ \\
\hline 3 & Secretary & /'sekrə,teri/ & /'sekrətri/ \\
\hline 4 & Temporary & /'tempəreri/ & /'temprəri/ \\
\hline
\end{tabular}

Table 1 . The difference between synchronic patterning of schwa in GA and SBS

Whereas schwa is optional in certain positions in SBS, especially as far as the pronunciation of suffixes is concerned (see Table 1), a reverse phenomenon of schwa insertion is found in Irish English (IrE) and Scottish English (ScE). In these varieties of the English language, schwa is inserted in a number of consonant clusters, for instance $/ 1 /+$ a consonant in IrE (Hickey 2007) and the insertion of schwa in $/ \mathrm{lm} /, / \mathrm{rm} /, / \mathrm{rn} /$ and $/ \mathrm{rl} /$ in ScE (Maguire 2018).

Since schwa is frequent in the English language, it seems logical to assume that EFL learners on the intermediate level of EFL proficiency, i.e. on the B1/B2 levels according to the Common European Framework of Reference for Languages, or CEFR (The Council of Europe 2011), are bound to be exposed to schwa in EFL instructional settings. In this regard, Pennington (2014: 94) observes that schwa poses pronunciation difficulties to the majority of EFL students whose first language (L1) backgrounds are characterised by a lack of vowel reduction, for instance, Italian (Wheelock 2016), Korean (Lee 2020), and Spanish (Monroy-Casas 2011). In particular, the literature (Hunt-Gómez and Navarro-Pablo 2020; MonroyCasas 2011) provides evidence of frequent mistakes made by Spanish L1 EFL learners, who substitute schwa for monophthongs (e.g., /a/ instead of $/ \mathrm{\partial} /$ in policeman /po'lisman/) and diphthongs (/io/ instead of /o/ in television /tele'vision/), whereas Italian L1 EFL learners (Wheelock 2016: 47) appear to insert schwa in atypical positions (e.g., / sopo/ in soup). Similarly to Italian and Spanish, there is no schwa in the Korean language, hence Korean L1 EFL learners are reported to substitute it for $/ \Lambda /$ (Lee 2020: 105).

Whilst the current literature indicates that EFL learners from a variety of L1 backgrounds encounter difficulties with schwa (Hunt-Gómez and Navarro-Pablo 2020; Lee 2020; Monroy-Casas 2011; Wheelock 2016), 
little is known about schwa as a problem to Norwegian L1 EFL students on the intermediate level of proficiency (Rugesæter 2014). In addition, there are insufficient studies that investigate the use of schwa by Norwegian L1 EFL learners in conjunction with the phonetic transcription (either in the broad or narrow sense). Arguably, a scientific inquiry into the use of schwa by Norwegian L1 intermediate EFL learners would be a promising avenue of research given that prior studies (Kapranov 2019a; Kapranov $2019 b)$ report that EFL teachers in Norway consider schwa a problematic sound to Norwegian L1 EFL learners, especially on the beginner's level of proficiency in English. Based upon the literature (Kapranov 2019a), this study seeks to shed light on schwa as a potential challenge to Norwegian L1 EFL students (further in the article - "participants") on the intermediate level of EFL proficiency. Following Mompean and Fouz-González (2021), phonemic transcription in the IPA is employed in the study as a means of identifying schwa-related errors made by the participants. The study seeks to address the following research questions:

RQ1: Would there be schwa-related errors in the participants' phonemic transcriptions in the IPA?

RQ2: Does a variety of the English language, specifically GA and SBS, impact upon schwa-related errors in the participants' phonemic transcriptions in the IPA?

Further, this article proceeds as follows. First, prior research that deals with schwa as a challenge to EFL learners is discussed. Thereafter, the article presents an overview of the recent literature associated with the role of phonemic transcription in EFL teaching and learning. Afterwards, a brief explanation of the context of EFL teaching and learning in Norway is provided. Following that, the present study is introduced and discussed. Finally, the article is concluded with the summary of the findings and their linguo-didactic implications.

\section{Schwa as a challenge to EFL learners}

As mentioned in the introduction, the use of schwa poses challenges to EFL learners (Lee 2020; Levis 2018; Pennington 2014). In this regard, Ahn (1997: 258) indicates that the sources of difficulty stem from the 
following two variables, namely i) the pronunciation of schwa is not reflected in the orthographic system of English and ii) the lack of an EFL learner's understanding of the phonetic and phonological properties of schwa. This observation is echoed by Nilsen and Rugesæter (2015), who indicate that one of the main problems that a Norwegian L1 EFL learner experiences is associated with vowel reduction in English, which involves the pronunciation of unstressed syllables as schwa. Another variable that is related to EFL learners' difficulties with schwa is accounted by the absence of schwa in their L1. In this regard, Nilsen and Rugesæter argue that "schwa is by far the most common vowel in English. In Norwegian, on the other hand, it is very rare" (2015: 89). The absence of schwa and, obviously, a host of other variables can lead to schwa-related errors that an EFL learner may encounter.

There are several fairly recent studies that specifically address the use of schwa by EFL learners by means of investigating it either in conjunction with other segmental properties of the English language (Bardakci 2015; Bryła-Cruz 2021; Hunt-Gómez and Navarro-Pablo 2020; Kapranov 2019a; Makino 2009; Rehman et al. 2020; Smith 2012; Wheelock 2016) or focusing exclusively on schwa as a source of difficulty to EFL learners (Hida 2020; Lacabex et al. 2008; Lee 2020; Rahal 2016). In particular, Lacabex, Lecumberri and Cooke (2008) examine the Spanish L1 EFL learners' ability to identify the English phonological contrast "full vowel - schwa" in two experimental conditions (auditory and articulatory) that involve the learners' perceptual performance of the contrast in isolation and in utterances. They conclude that phonetic training exhibits positive effects upon the perception and use of schwa by the participants in the study. Hida (2020) examines the effect of direct pedagogical intervention in the form of shadowing on the learners' ability to pronounce schwa. In the same vein as Lacabex, Lecumberri and Cooke (2008), Hida (2020) concludes that explicit didactic strategies of teaching schwa to EFL learners have positive effects on the correct pronunciation. Notably, Lee (2020) arrives at identical conclusions as far as the explicit teaching of schwa in Korean EFL contexts is concerned. Lee's (2020) findings are supported by the study conducted by Rahal (2016), who argues that schwa is a common error among Arabic L1 EFL learners. According to Rahal (2016), schwarelated errors are associated with the learners' insufficient awareness of the phonetic properties of schwa. 
In contrast to the aforementioned studies, Bardakci (2015), BryłaCruz (2021), Hunt-Gómez and Navarro-Pablo (2020), Kapranov (2019a), Makino (2009), Rehman, Silpachai, Levis, Zhao, and Gutierrez-Osuna (2020), Smith (2012), Visoni and Marlina (2020), and Wheelock (2016) analyse EFL learners' problems with schwa in conjunction with other mispronunciation phenomena. These authors adopt the so-called broad or global perspective on errors in an EFL learner's speech in order to identify a range of frequently mispronounced segmentals. Guided by this perspective, Bardakci (2015) argues that schwa is one of the most common mistakes made by Turkish L1 EFL learners. A possible reason that explains the high frequency of occurrence of schwa-related errors is the substitution of schwa for a similar Turkish vowel /w/ (Bardakci 2015). Unlike in Turkish, there is no schwa in such Romance languages as Italian and Spanish (at least, in their standard varieties), which leads to frequent errors in speech produced by EFL learners whose L1 are Italian (Wheelock 2016) and Spanish (Hunt-Gómez and Navarro-Pablo 2020). However, in contrast to Spanish L1 EFL learners, Italian L1 EFL students add schwa to the English words that end in a consonant (Wheelock 2016). Similarly to Italian and Spanish, schwa is absent in the phonological inventory of the standard Norwegian variety Bokmål, which poses problems to young EFL learners whose L1 is Norwegian (Kapranov 2019a). It is reported that Norwegian L1 EFL learners "have difficulties with pronouncing words like salad, forward with schwa /ə/. They pronounce schwa more like a lip rounding /Ø/ or /e/" (Kapranov 2019a: 309). In comparison to Norwegian L1 EFL learners, however, Japanese L1 EFL students make schwa-related mistakes due to i) "the various spellings corresponding to this sound" (Makino 2009: 26) and ii) "the relatively small number of vowels in Japanese and the places of articulation in the mid to low central area" (Smith 2012: 201). These variables result in frequent substitutions of schwa for diphthongs by Japanese L1 EFL learners, e.g., /ov/ instead of /ə/ in of (Makino 2009; Smith 2012). Likewise, a systematic error analysis conducted by Rehman, Silpachai, Levis, Zhao, and Gutierrez-Osuna (2020) has provided an account of persistent schwa-related errors made by Arabic L1 EFL learners. In an analogous manner, Visoni and Marlina (2020) indicate that schwa is a recurrent error in Indonesian L1 EFL learners' speech in English. A recent study conducted by Bryła-Cruz (2021) reports that schwa is associated with a repetitive type of errors by Polish L1 EFL learners. Notably, BryłaCruz (2021) has established that male EFL learners in her study make 
more schwa-related mistakes in comparison with female EFL learners on the same level of EFL proficiency.

The meta-analysis of the current literature suggests that schwa poses substantial problems to EFL learners from a variety of L1 backgrounds. The literature shares a common denominator that schwa-related errors should be addressed in EFL instructional contexts (Bardakci 2015; Hida 2020; Kapranov 2019a; Makino 2009; Smith 2012; Wheelock 2016).

\section{Recent studies on phonemic transcription in EFL teaching and learning}

One of the theoretical premises in this study involves the role of phonemic transcription as a means of EFL learners' error identification associated with the phonological properties of the English language (Mompean and Fouz-González 2021; Mompean and Lintunen 2015). It should be noted that starting from the 1990s, the application of phonemic transcription in an EFL classroom has been comprehensively described in applied linguistics and EFL studies (Jenkins 2004; Lintunen 2013; Mompean 2005; Wells 1996). The prior literature indicates that phonemic transcription is a valuable source of data that sheds light on EFL students' pronunciation errors (Mompean 2017: 480). The majority of publications in EFL studies (Jurida 2014; Lintunen 2005; Mompean 2005; Mompean and Lintunen 2015) share an assumption that errors made by EFL learners in phonemic transcription correlate with the analogous errors in their actual speech production in English. In other words, EFL learners seem to map their common pronunciation mistakes onto their phonemic transcriptions (Łodzikowski 2021; Mompean and Fouz-González 2021).

Whilst meta-analyses of the studies on phonemic transcription in EFL settings published prior to 2015 are amply represented in the literature (see Mompean and Lintunen 2015), there seems to be no systematic review of research on the topic published after 2015. Further, this article provides a brief outline of the recent studies (i.e., published in 2016 - 2021) that explore the use of phonemic transcription across several EFL contexts that involve EFL cohorts with such L1 backgrounds, as Polish (Łodzikowski 2021; Trzeciakowska 2016), Serbian (Tišma and Jeremić 2017), and Spanish (Mompean 2017; Mompean and Fouz-González 2021). 
Trzeciakowska (2016) investigates Polish L1 EFL students' errors in phonemic transcriptions in a variety of experimental tasks in order to reveal the connection between errors in transcription and pronunciation. She argues that there is a

[...] correlation between pronunciation and transcription skills. From this perspective, it can be assumed that transcription errors, which vividly resemble faulty pronunciations, should be treated as indicators of deficient knowledge about pronunciation skills.

(Trzeciakowska 2016: 180-181)

By means of examining a corpus of phonemic transcriptions in the IPA executed by the participants in her study, Trzeciakowska (2016: 175) has established that their mistakes in the IPA are ascribed to i) inadequate knowledge of transcription rules and ii) common pronunciation errors in the participants' speech in English. Similarly to the study conducted by Trzeciakowska (2016), Łodzikowski (2021) examines the use of the IPA in EFL settings in Poland. However, his study focuses on the IPA-based digital transcription tool that is employed in the course in English phonetics in order to facilitate the learners' phonological awareness. Łodzikowski (2021) indicates that the use of the digital transcription tool stipulates the learners' autonomy in the learning process, facilitates their phonological awareness, and helps them with the identification and correction of errors.

Along the lines of the study conducted by Łodzikowski (2021), Mompean (2017) as well as Mompean and Fouz-González (2021) develop the construal of phonological awareness in conjunction with the use of phonemic transcription. In particular, Mompean (2017) operationalises phonological awareness as an EFL learner's sensitivity to the sound structure of the English language. He indicates that the use of phonemic transcription draws EFL learners' attention to linguistic details, contributes to a better sound discrimination both in isolation and within the speech stream, and fosters their capability of auditory discrimination. Based upon the study by Mompean (2017), Mompean and Fouz-González (2021) argue that the linguo-didactic value of phonemic transcription consists in providing the learners with a framework for autonomous learning of the English sounds. In addition, Mompean and Fouz-González (2021) suggest that phonemic transcription should be taught concurrently with practicing pronunciation skills. 
The aforementioned contention is echoed by Tišma and Jeremić (2017), who investigate the methodology of teaching phonemic transcription to Serbian L1 EFL learners. Specifically, Tišma and Jeremić (2017) compare two methods, the traditional teaching of broad phonemic transcription based upon rote memorisation and the novel approach developed by Underhill (2005) that "attempts at making articulation empirically testable, i.e., visible, even touchable" (Tišma and Jeremić 2017: 590). Whereas the results of the comparison reveal that both the traditional and novel methods of teaching phonemic transcription are regarded favourably by the learners, the latter appears to be associated with fostering the learners' autonomy and their active engagement in the learning process.

Summarising the recent publications, it seems possible to observe that the literature emphasises a facilitative role of the IPA transcription in EFL learners' phonological awareness (Łodzikowski 2021; Mompean 2017; Mompean and Fouz-González 2021; Tišma and Jeremić 2017; Trzeciakowska 2016). It should be noted, however, that there are no current studies that elucidate the role of phonemic transcription in the EFL context in Norway. Further, a brief outline of the context of EFL teaching and learning in Norway is provided.

\section{The context of EFL teaching and learning in Norway}

Current research indicates that Norwegians have a generally high level of EFL proficiency (Busby 2021). The English language in Norway has become a part of Norwegian speakers' linguistic repertoire due to its increasing use (Rindal and Piercy 2013). Whilst Norwegians do not speak English as a second language (Ibid.), the presence of English in Norwegian educational contexts is significant to such an extent that it is no longer regarded as EFL (Vattøy 2019). Arguably, English in Norway occupies the niche between a second and a foreign language, since it is considered "a natural, supranational language in modern Norwegian society" (Chvala 2020: 1).

In terms of the EFL teaching and learning context in Norway, it should be observed that students are expected to start formal EFL instruction in Year 1 of primary school and continue their EFL studies until Year 10, i.e. by the end of the so-called lower secondary school. At primary and lower secondary school, Norwegian EFL students are assumed to have 
been exposed to 588 contact hours of English (Vattøy 2019). As far as the Norwegian EFL curriculum is concerned, it follows the can-do statements formulated by the Common European Framework of References for Languages (The Council of Europe 2011).

Based upon the revised curriculum, the Norwegian Directorate for Education and Training (Udir in Norwegian) regards the teaching and learning of English pronunciation as an integral part of communicative skills. Specifically, Udir (2021) mandates that

Communication is achieved through listening, reading, writing, prepared oral production and spontaneous oral interaction, including the use of appropriate communication strategies. It also includes participation in various social arenas, where it is important to train to master an increasing number of genres and forms of expression. Good communication requires knowledge and skills in using vocabulary and idiomatic structures, pronunciation, intonation, spelling, grammar and syntax of sentences and texts. (Udir 2021)

It follows from the revised subject curriculum (Udir 2021) that an EFL learner's familiarity with English pronunciation and intonation is one of the institutionalised requirements of the teaching and learning process. In reality, however, insufficient attention is awarded to phonetics in primary and lower secondary schools (Rugesæter 2014). This observation is echoed by Bøhn and Hansen (2017: 55), who argue that little is known about how pronunciation is taught and assessed in Norway.

One of the peculiarities of the current Norwegian EFL context lies in the rare use of the IPA in an EFL classroom (Bøhn and Hansen 2017; Rugesæter 2014). For instance, the IPA does not seem to be employed in order to teach the English sounds that cause substantial difficulties to Norwegian L1 EFL learners, such as $/ \theta /, / \partial /, / \mathrm{z} /$, and /w/ (Rugesæter 2014). It could be argued that there exists a discrepancy between the institutionalised goal of teaching the English sound system and the lack of focus on phonetics and "little guidance in the assessment of pronunciation" (Bøhn and Hansen 2017: 55) in a Norwegian EFL classroom. In this regard, Bøhn and Hansen (Ibid.) observe that whereas Norwegian L1 EFL students are expected by Udir (2021) to use language-appropriate patterns in their oral communication in English, there are no clear guidelines concerning 
what these patterns involve in terms of pronunciation and intonation and what an EFL teacher should do in order to teach them.

Given that the teaching and learning of English phonetics is not prioritised and the IPA is not used at school often, a typical Norwegian L1 EFL learner might experience a number of difficulties with the English sounds even on the intermediate level of proficiency (Rugesæter 2014). Arguably, one of those difficulties is associated with schwa. The following section of the article presents and discusses a study that seeks to establish whether or not schwa is problematic to Norwegian L1 EFL learners.

\section{The present study}

The present study is embedded in the instructional setting of a course in English Phonetics offered at a regional university in Norway. The course in English Phonetics is a part of the so-called Arsstudium (Year Course in English), which is a stand-alone full-time university course comprised of such modules as Functional Grammar of English, EFL Didactics, English Literature, and Anglo-Saxon Civilization. The course in English Phonetics is based upon the book English Phonetics for Teachers by Nilsen and Rugesæter (2015). Following the book, the course is structured as a series of seminars (see Table 2 below that summarises seminar topics).

\begin{tabular}{|c|c|c|}
\hline N & Seminars & Seminar Topics \\
\hline 1 & Seminar 1 & $\begin{array}{c}\text { Introduction. Course expectations and } \\
\text { requirements. }\end{array}$ \\
\hline 3 & Seminars 2-3 & $\begin{array}{c}\text { Articulation. Phoneme and allophone. } \\
\text { Syllable. }\end{array}$ \\
\hline 4 & Seminars 4-5 & $\begin{array}{c}\text { Consonants. Stops. Fricatives. Nasals. } \\
\text { Approximants. }\end{array}$ \\
\hline & Seminars 6-7 & $\begin{array}{c}\text { Vowels. The front monophthongs. } \\
\text { The central monophthongs. The back } \\
\text { monophthongs. The weak vowels. } \\
\text { The front closing diphthongs. The } \\
\text { back closing diphthongs. The centring } \\
\text { diphthongs. }\end{array}$ \\
\hline
\end{tabular}




\begin{tabular}{|c|c|c|}
\hline 5 & Seminars 8-9 & $\begin{array}{c}\text { Word stress. Sentence stress. Weak } \\
\text { forms. Assimilation and elision. }\end{array}$ \\
\hline 6 & Seminars 10-11 & Intonation. The five basic tones. \\
\hline 7 & Seminars 12-13 & $\begin{array}{c}\text { Teaching pronunciation in an EFL } \\
\text { classroom. }\end{array}$ \\
\hline 8 & Seminars 14-15 & Varieties of spoken English. SBS. GA. \\
\hline
\end{tabular}

Table 2. The structure of the course in English Phonetics

Elements of the IPA are introduced starting from the English consonants at Seminar 3 and adding English vowels at Seminar 6. Phonemic transcription is taught explicitly with substantial emphasis on practicing it in class and at home. Whilst phonemic transcription is focused on SBS during the first semester (Seminars 1-7), elements of GA are discussed in parallel with SBS starting from Seminar 3. During the second semester (Seminars 8-15), the focus on phonemic transcription shifts towards GA. However, GA is discussed in contrast with SBS at Seminars 8-15. The application of phonemic transcription to other varieties of the English language (e.g., IrE) is not addressed in the course.

The study is inspired by the previous literature (Kapranov 2019a), which indicates that schwa is regarded as one of the sources of difficulties to Norwegian L1 young EFL learners on the A1/A2 levels of EFL proficiency according to CEFR (The Council of Europe 2011). In line with the literature (Kapranov 2019a), the study seeks to examine whether or not schwa is associated with difficulties posed to a group of participants, who are Norwegian L1 EFL learners on the intermediate level of proficiency in the English language (i.e., on the B1/B2 levels). In contrast to the previous studies (Kapranov 2019a), however, this investigation focuses exclusively on schwa without identifying and discussing other segmental elements of the English language that the participants find problematic in their speech production in English.

In line with Mompean and Fouz-González (2021), phonemic transcription in the study is regarded as a diagnostic means of error identification. Hence, the hypothesis suggests that the participants' potential difficulties with schwa would be manifested as schwa-related errors in their phonemic transcriptions in the IPA. As mentioned in the introduction, the study seeks to answer two research questions that focus 
on i) the identification of schwa-related errors in the participants' phonemic transcriptions and ii) the impact of GA and SBS upon schwa-related errors in the phonemic transcriptions. Based upon the hypothesis and the research questions, the study involves a series of phonemic transcriptions in the IPA executed by the participants and a post-hoc procedure that consists in the participants' spontaneous oral narratives in English.

\subsection{Participants}

In total, there are 15 participants $(10$ females and 5 males, $\mathrm{M}$ age $=$ 23.1 y.o., SD $=6$ ) in the study. All the participants are intermediate EFL learners who at the time of the study were enrolled in an EFL programme at a regional university in Norway. The participants' L1 is Norwegian. As far as the participants' L1 background is concerned, it should be explained that Norwegian and Saami are two official languages in Norway, whilst Kven and Romani are regional and minority languages (Hiss, Pesch and Sollid 2021). There are no participants who are associated with the sociolinguistic backgrounds other than Norwegian. The participants indicate that they speak Vestlandsk, a dialect of the Norwegian language spoken in Western Norway.

English is a foreign language to all the participants. There are neither English L1 speakers nor early balanced English/Norwegian bilinguals among them. The participants are assumed to be on the intermediate B1/B2 levels of proficiency in English according to CEFR (The Council of Europe 2011). This assumption is based upon their secondary school leaving certificates. In terms of the participants' preferences for a particular English variety, the following should be explained. In an informal discussion at one of the seminars in English Phonetics, nine participants (60\%) have reported that they prefer using SBS, five participants $(33,3 \%)$ speak GA, whereas one participant $(6,6 \%)$ uses ScE. These findings correspond to the previous literature (Kapranov 2019c; Rindal and Piercy 2013) which indicates that Norwegian L1 EFL learners typically exhibit preferences for GA and SBS as the varieties that they use in class and extra-murally.

The participants are requested to sign a Consent form that allows the author of the present article to process, analyse and publish their written data for scientific purposes. To ensure confidentiality, the participants' real names are coded. The following coding scheme is used in the study, e.g. P as in "participant" and the number (P1, P2, .. P15). 


\subsection{Materials, methods and procedure}

The study involves a series of phonemic transcriptions (total $\mathrm{N}$ of tasks $=$ 4) that are executed by the participants during the course of two semesters, i.e. Task 1, Task 2, Task 3, and Task 4. All four tasks involve the so-called broad phonemic transcriptions in the IPA.

The materials in all four tasks are derived from short texts $(\mathrm{N}=4)$ that provide general plot synopses for popular feature films on the web-site Internet Movie Database (www.imdb.com). The Internet Movie Database (also abbreviated as IMDb) is an online database of "information related to movies, television programs and video games, including cast, production crew, fictional characters, biographies, plot summaries and reviews" (Fornacciari et al. 2017: 5). The use of the general plot synopses of feature films as materials for the tasks is explained by the tendency of the IMDb to provide an easy-to-understand descriptive narrative about the film and the main characters in the film (Goldstein et al. 2007).

The materials in all four tasks are edited by the author of the article to ensure that they do not pose substantial problems to the participants in terms of the lexical and syntactic complexity. After the materials have been edited, they are comprised of frequently used non-specialist vocabulary items and the maximum of two T-units per sentence. All the materials that are used in the transcription tasks are stylistically neutral narratives. The texts that are used in Tasks 1-2 are lexically and syntactically similar in terms of the total number or words, sentences, and T-Units. The author of this study follows the definition of the T-unit, or minimal terminable unit of language, provided by Hunt (1965), who defines it as "a single main clause (or independent clause) plus whatever other subordinate clauses or non-clauses are attached to, or embedded within, that one main clause" (Hunt 1965: 93). Whilst Tasks 3 and 4 differ in the total number of words, they are identical in terms of the total number of sentences and T-Units, as seen in Table 3 below. 
Oleksandr Kapranov: The English Vowel Schwa as a Difficulty to Intermediate EFL...

\begin{tabular}{|c|c|c|c|c|c|}
\hline $\mathbf{N}$ & $\begin{array}{c}\text { Descriptive } \\
\text { Statistics }\end{array}$ & Task 1 & Task 2 & Task 3 & Task 4 \\
\hline 1 & Total N of words & 30 & 39 & 88 & 122 \\
\hline 2 & $\begin{array}{c}\text { Total N of } \\
\text { sentences }\end{array}$ & 4 & 2 & 4 & 4 \\
\hline 3 & $\begin{array}{c}\text { Total N of } \\
\text { T-Units }\end{array}$ & 4 & 4 & 10 & 10 \\
\hline
\end{tabular}

Table 3. The descriptive statistics of the texts used in Tasks 1-4

From the point of view of research methodology, the approach to error identification in the tasks (i.e., Tasks 1 - 4) should be explained in detail. The author of this article concurs with Lintunen (2005), who posits that EFL learners' errors associated with English vowels are problematic to identify and compare due to difficulties in the limits of acceptability. In this regard, Vishnevskaya (2011: 78) argues that acceptability may involve the levels of variability associated with the varieties of English, word stress patterns, and phonetic variation in English polysyllabic words, to name just a few. Taking these variables into account, error identification in this study factors in phonetic variability. In order to illustrate the procedure of error analysis, let us consider how phonemic transcription of the noun expectations is analysed in the study. Both /,ekspek'terfonz/ and /,ekspek'terfnz/ are accepted and, consequently, not identified as errors, whilst, for instance, /.ekspek'ter $\int \mathfrak{p n z} /$ is counted as a mistake. Additionally, the procedure of error identification in the study factors in textual constrains of the tasks. It means that the materials in Tasks $1-4$ do not involve individual words in isolation. Subsequently, the materials in the tasks should not be transcribed as individual stand-alone lexical items. For instance, in the present error analysis the transcription of the indefinite article $a$ as /æ/ and/or /eI/ in the sentence It's a cat is counted as a mistake, whereas the transcription of $a$ as/ə/ is considered to be correct. Prior to each task, the participants have been reminded about the importance of paying attention to transcribing sounds in the speech flow and observing the stress in phonetic words and sentences rather than stressing all individual words. Furthermore, the participants are advised that the texts in all four tasks are stylistically neutral and non-emphatic. 
Guided by the aforementioned approach to error identification, the participants' phonemic transcriptions in the tasks are analysed quantitatively per group. First, the participants' errors associated with schwa are manually identified in the tasks by the author of the article and converted into numerical representations that are subsequently entered into the Statistical Package for Social Sciences, or SPSS (IBM 2011). Thereafter, means and standard deviations per error type per group are computed in SPSS (IBM 2011). Second, the percentage of the participants who have made errors associated with schwa per type of error per group is calculated in SPSS. Finally, the participants' errors are double-checked by an experienced phonetician who works at the university examination board.

As far as the procedure in the study is concerned, the participants are requested to transcribe Tasks 1 and 2 in the IPA in SBS in the first semester of the course in English Phonetics, while Tasks 3 and 4 are transcribed by the participants in the second semester of the course. Task 3 is requested to be transcribed in the IPA in SBS, whereas Task 4 is asked to be transcribed in the IPA in GA. All tasks are executed by the participants electronically on their personal computers at home. In addition, after the completion of all tasks, the participants are requested to record spontaneous oral narratives that are analysed in the post-hoc procedure.

\subsection{Results}

The error analysis has revealed several types of schwa-related errors made by the participants in all four tasks. These errors are summarised in Table 4 in the form of means (M) and standard deviations (SD) per group. 
Oleksandr Kapranov: The English Vowel Schwa as a Difficulty to Intermediate EFL...

\begin{tabular}{|c|c|c|c|c|c|}
\hline $\mathbf{N}$ & Error type & Task 1 & Task 2 & Task 3 & Task 4 \\
\hline 1 & $\begin{array}{l}\text { /e/ instead } \\
\text { of } / \mathrm{\partial} /\end{array}$ & $\begin{array}{c}\text { M 1.1 } \\
\text { (SD 0.3) }\end{array}$ & $\begin{array}{c}\text { M } 4 \\
\text { (SD 2) }\end{array}$ & M 1 (SD 0) & $\begin{array}{c}\text { M } 2.5 \text { (SD } \\
3.3)\end{array}$ \\
\hline 2 & $\begin{array}{c}/ \mathrm{p} / \text { instead } \\
\text { of } / \mathrm{\partial} /\end{array}$ & $\begin{array}{c}\text { M } 1 \\
\text { (SD 0) }\end{array}$ & $\begin{array}{c}\text { M } 2.1 \\
\text { (SD 0.8) }\end{array}$ & $\begin{array}{c}\text { M } 1.2 \text { (SD } \\
0.4)\end{array}$ & $\begin{array}{c}\text { M } 4.6(S D \\
1.7)\end{array}$ \\
\hline 3 & $\begin{array}{c}/ æ / \text { instead } \\
\text { of } / \mathrm{\partial} /\end{array}$ & $\begin{array}{c}\text { M } 1.6 \\
\text { (SD 0.9) }\end{array}$ & $\begin{array}{c}\text { M } 1.8 \\
\text { (SD 4.9) }\end{array}$ & $\begin{array}{c}\text { M } 1 \text { (SD } \\
0.7)\end{array}$ & $\begin{array}{c}\mathrm{M} 4.8 \text { (SD } \\
1.2)\end{array}$ \\
\hline 4 & $\begin{array}{c}/ \Lambda / \text { instead } \\
\text { of } / \partial /\end{array}$ & - & $\begin{array}{c}\text { M } 1.4 \\
\text { (SD 0.5) }\end{array}$ & $\begin{array}{c}\text { M } 2.3 \text { (SD } \\
0.9)\end{array}$ & - \\
\hline 5 & $\begin{array}{c}\text { /a:/instead } \\
\text { of } / \mathrm{a} /\end{array}$ & $\begin{array}{c}\text { M } 1.3 \\
(\mathrm{SD} 0.5)\end{array}$ & $\begin{array}{c}\text { M } 1 \\
(\text { SD 0) }\end{array}$ & $\begin{array}{c}\text { M } 3.5 \text { (SD } \\
2.5)\end{array}$ & - \\
\hline 6 & $\begin{array}{c}\text { /3:/ instead } \\
\text { of } / \mathrm{\partial} /\end{array}$ & - & $\begin{array}{c}\text { M } 1 \\
(\text { SD 0) }\end{array}$ & - & - \\
\hline 7 & $\begin{array}{c}/ v / \text { instead } \\
\text { of } / \partial /\end{array}$ & $\begin{array}{c}\text { M } 1 \\
\text { (SD 0) }\end{array}$ & - & $\begin{array}{c}\text { M } 6.7 \text { (SD } \\
1)\end{array}$ & M 2 (SD 1) \\
\hline 8 & $\begin{array}{c}\text { /el/ instead } \\
\text { of } / \partial /\end{array}$ & - & - & - & $\begin{array}{c}\text { M } 1.8 \text { (SD } \\
0.4)\end{array}$ \\
\hline
\end{tabular}

Table 4. Means and standard deviations of errors associated with schwa

Table 5 illustrates the percentage of participants per group, who made schwa-related mistakes.

\begin{tabular}{|c|c|c|c|c|c|}
\hline $\mathbf{N}$ & Error type & Task 1 & Task 2 & Task 3 & Task 4 \\
\hline 1 & $\begin{array}{l}\text { /e/ instead } \\
\text { of } / \mathrm{\partial} /\end{array}$ & $46.6 \%$ & $53.3 \%$ & $13.3 \%$ & $40 \%$ \\
\hline 2 & $\begin{array}{c}/ \mathrm{p} / \text { instead } \\
\text { of } / \mathrm{\partial} /\end{array}$ & $6.6 \%$ & $46.6 \%$ & $33.3 \%$ & $40 \%$ \\
\hline 3 & $\begin{array}{c}/ æ / \text { instead } \\
\text { of } / \curvearrowright /\end{array}$ & $73.3 \%$ & $40 \%$ & $46.6 \%$ & $60 \%$ \\
\hline 4 & $\begin{array}{c}/ \Lambda / \text { instead } \\
\text { of } / \mathrm{\partial} /\end{array}$ & - & $33.3 \%$ & $20 \%$ & - \\
\hline 5 & $\begin{array}{c}\text { /a:/instead } \\
\text { of } / \mathrm{\partial} /\end{array}$ & $40 \%$ & $26.6 \%$ & $13.3 \%$ & - \\
\hline
\end{tabular}




\begin{tabular}{|c|c|c|c|c|c|}
\hline 6 & $\begin{array}{c}/ 3: / \text { instead } \\
\text { of } / \mathrm{\partial} /\end{array}$ & - & $6.6 \%$ & - & - \\
\hline 7 & $\begin{array}{c}/ \mathrm{v} / \text { instead } \\
\text { of } / \mathrm{\partial} /\end{array}$ & $26.6 \%$ & - & $60 \%$ & $40 \%$ \\
\hline 8 & $\begin{array}{c}/ \mathrm{e} / \text { instead } \\
\text { of } / \mathrm{\partial} /\end{array}$ & - & - & - & $26.6 \%$ \\
\hline
\end{tabular}

Table 5. Percentage of participants, who made errors associated with schwa

\subsection{Discussion}

As mentioned in the introduction, the study seeks to provide answers to two research questions. Whereas the first research question is concerned with the identification and classification of schwa-related errors in the participants' phonemic transcriptions in the IPA, the second research question aims to answer whether or not a variety of the English language impacts upon errors associated with schwa in the participants' phonemic transcriptions. These research questions will be discussed in detail in the following subsections of the article.

\subsubsection{Discussing research question 1}

It is evident from Table 4 that whilst schwa-related errors are present in all tasks, the types of errors and their distribution in the tasks differ. Figure 1 below illustrates the difference between the distribution of error types in Tasks 1 and 2 . 


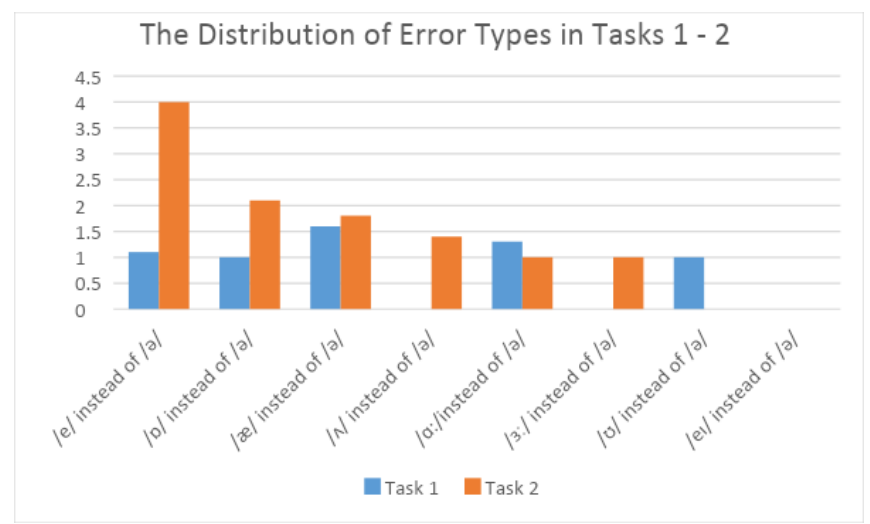

Figure 1. The distribution of schwa-related error types in Tasks 1 and 2

As previously described in the article, Tasks 1 and 2 involve texts that are phonologically balanced and similar in terms of the number of words to be transcribed (see Table 3). Furthermore, Tasks 1 and 2 are offered to the participants for transcription in the first semester of the course in English phonetics, when the participants could be assumed to be at the initial stage of familiarity with the IPA. Additionally, the participants are instructed to transcribe both Task 1 and Task 2 in SBS. Arguably, these variables render the tasks comparable as far as the error analysis in the present study is concerned.

The results of the error analysis indicate that there are several types of errors associated with schwa that involve a substitution of schwa for another vowel (see Table 4). Several error types have been identified both in Task 1 and Task 2, for instance, the substitutions of /ə/ for /e/, /p/, /æ/, and /a:/. These errors could be related to a number of variables, such as the influence of the English orthography, a nascent stage of transcription skills, and, perhaps, an over-taxed capacity of the participants' long-term memory associated with the retention of the IPA symbols in order to use them properly in the transcriptions. Another variable could involve the participants' insufficient attention to schwa due to the focus on the transcription of the English consonants that are absent in the Norwegian language, such as $/ \mathrm{z} /, / \theta /$, and $/ \partial /$. Whilst it is beyond the scope of this study to provide a comprehensive error analysis, it should be mentioned that $93 \%$ of the participants make mistakes by substituting the fricative 
/z/ for /s/. The lack of understanding of the /s/ - / z/ contrast in English by the participants has been one of their major challenges during the course in English Phonetics. Arguably, the participants have redirected their cognitive resources, attention, and working memory allocation from schwa towards transcribing other sounds, for instance /z/. Subsequently, this phenomenon may contribute to the increase in schwa-related errors in Task 2 even after the participants have received more instruction associated with phonemic transcription in the IPA.

Whereas the substitutions of $/ \mathrm{\partial} /$ for other vowels (for instance, /e/, / $/ /, / æ /$, and /a:/) are similar in Tasks $1-2$ (see Figure 1), the substitution of $/ \mathrm{\partial} /$ for $/ \mathrm{e} /$ increases in Task 2 . In this task, nearly one half of the participants (46.6\%) make this mistake (see Table 5). The substitution of $/ \mathrm{\partial} /$ for $/ \mathrm{e} /$, especially in Task 2 , could be explained by the following reasons. First, the participants have insufficient skills in the IPA transcription in the first semester of the course. Obviously, the lack of skills in transcription affects not only the correct transcription of schwa, but other vowels and some consonant sounds as well (e.g., the English fricative /z/ is consistently transcribed by the participants as $/ \mathrm{s} /$ ). It should be noted that similar observations are made by Mompean (2017), Tišma and Jeremić (2017), and Trzeciakowska (2016), who suggest that low levels of the IPA transcription skills correlate with the errors in phonemic transcription in the IPA irrespective of an EFL's learner understanding of the phonetic and phonological properties of the English language. Notably, the same pattern of substitution of schwa for /e/ is reported in the study by Rahal (2016), who attributes this error to an EFL learner's insufficient awareness of the phonetic properties of schwa. Second, the spike in the substitution of $/ \mathrm{a} /$ for $/ \mathrm{e} /$ in Task 2 could be explained by means of referring to the conclusions made by Łodzikowski (2021), Mompean and Fouz-González (2021), Tišma and Jeremić (2017), and Trzeciakowska (2016), who point to the orthographic system of English as a cause EFL students' difficulties associated with schwa. Judging from the data, the major bulk of the substitution of /a/ for /e/ in Task 1 and, especially, in Task 2 occurs in the definite article the, which the participants transcribe as /ðe/. Given that there is neither /ðI/ nor /ði:/ in the data, the stress placement as a cause of this error should be factored out. Hence, it is argued that the error in the substitution of /o/ for /e/ is caused, predominantly, by the impact of the English spelling upon the participants' transcriptions in the IPA. 
Judging from the data, another error is manifested by the substitution of schwa for /æ/ in Tasks 1 and 2. This error in Task 1 appears to be confined, mostly, to the transcription of and (e.g., /ænd/ instead of / ənd/). This type of error is made by $73.3 \%$ of the participants and its mean occurrence per group in Task 1 is $\mathrm{M}=1.6$ (SD 0.9). The results of the error analysis indicate that 11 out of 15 participants have made between one and two errors of this type in their IPA transcriptions. It seems that the high percentage of the participants who substitute /ə/ for /æ/ in Task 1 is reflective of the participants' problems with i) the English stress on the level of phrase and sentence and, concurrently with that, ii) insufficient understanding of the phonetic and phonological properties of schwa.

Data analysis indicates that only two participants do not have schwarelated mistakes in their transcriptions in Tasks $1-2$. This finding is illustrated by Figure 2 that presents the number of errors per participant in Tasks $1-2$.

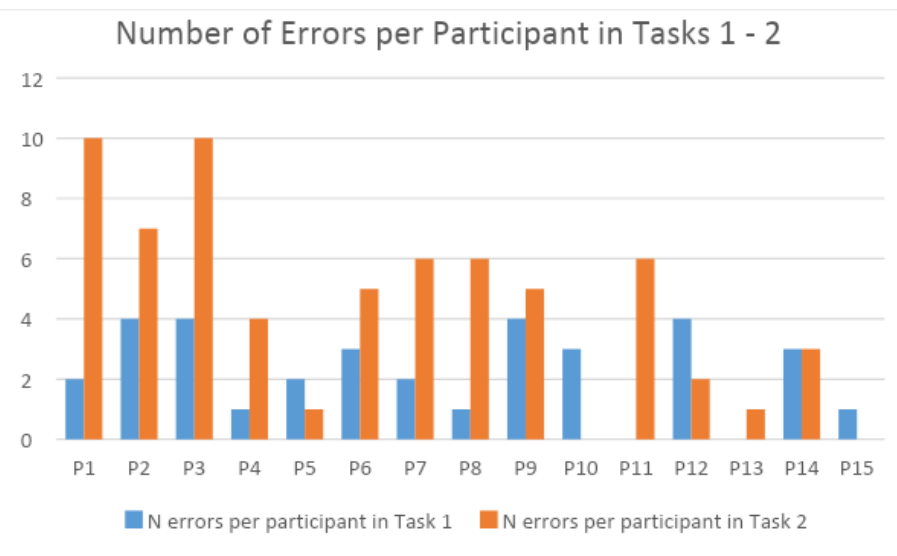

Figure 2. The number of errors per participant in Tasks $1-2$

It is evident from Figure 2 that the standard deviation of all error types per group in Task 2 is higher ( $\mathrm{SD}=2,81$ ) in contrast to that of Task 1 (SD = 1,14). This finding illustrates that several participants (for instance, P1, P2, P3, P7, P8, P11) make the major bulk of the schwa-related errors, whereas the rest of the participants make between one and two errors in Tasks 1 and 2 (see Figure 2). Judging from the observations of the participants 
at the seminars in English Phonetics, one of the reasons for the increase in schwa-related errors could be attributed to the participants' individual differences in mastering phonemic transcription in the IPA. Specifically, the author of this article, who was the course teacher, noted that a group of participants (namely, P1, P2, P3, P7, P8, P11) required more help with the completion of the transcription tasks and demonstrated problems with remembering and retaining the IPA symbols. This observation feeds into the construal of individual differences in the EFL learning process that highlights the relevance of psychological and individual factors in mastering pronunciation (Pennington 2021: 3).

\subsubsection{Discussing research question 2}

The second research question addresses how schwa-related errors are distributed depending on whether or not the participants transcribe the tasks in SBS or GA. In order to elucidate this issue, the participants have been asked to transcribe one text in SBS in Task 3 and one text in GA in Task 4. It should be specified that the text in Task 3 is written in accordance with British spelling conventions, whereas the text in Task 4 is written in American English. The results of the error analysis reveal that the participants make schwa-related mistakes regardless of the variety of the English language. Arguably, this finding seems to be novel given that the prior literature (Łodzikowski 2021; Mompean and Fouz-González 2021; Tišma and Jeremić 2017; Trzeciakowska 2016) does not report the correlation between the occurrence of schwa-related errors and the variety of English. The application of the one-way analysis of variance (ANOVA) to the means of error types in Tasks $3-4$ indicates that the result is not significant at $p<.05,[\mathrm{~F}(1 ; 22)=0.39, p=.54]$. Judging from this finding, the distribution of schwa-related errors in Tasks 3 and 4 appears to be similar.

However, in terms of the raw values, the substitution of schwa for $/ \mathrm{p} /$ and /æ/ is more common in Task 4. It appears to be associated with the participants' errors in transcribing the prepositions of as / $\mathrm{pv} /$ instead of /əv/ and on as /pn/ instead /ən/. The substitution of schwa for /æ/ is illustrated by the participants' transcriptions of the preposition as as /æz/, and the conjunction and as /ænd/ instead of /ond/. These errors could be accounted by the participants' reliance on the English spelling whose rules are, presumably, mapped onto the respective transcriptions. In addition, 
the errors are indicative of the participants' insufficient understanding of the vowel reduction in weak forms and a lack of awareness of how functional words are transcribed on the sentence level.

It follows from the results of the error analysis that there are several substitutions of schwa for monophthongs in the participants' transcriptions both in SBS and GA. Specifically, schwa is substituted for $/ \mathrm{e} /, / \mathrm{p} /, / \mathfrak{\text { r }}$, and $/ \mho /$ regardless of the aforementioned varieties of the English language. However, the substitution of schwa for $/ \Lambda /$ and /a:/ occurs only in the transcriptions in SBS, whereas the substitution of schwa for the diphthong /eI/ is an error found only the participants' transcriptions in GA. These findings are exemplified by Figure 3 below.

\section{The Distribution of Error Types in Tasks 3 - 4}

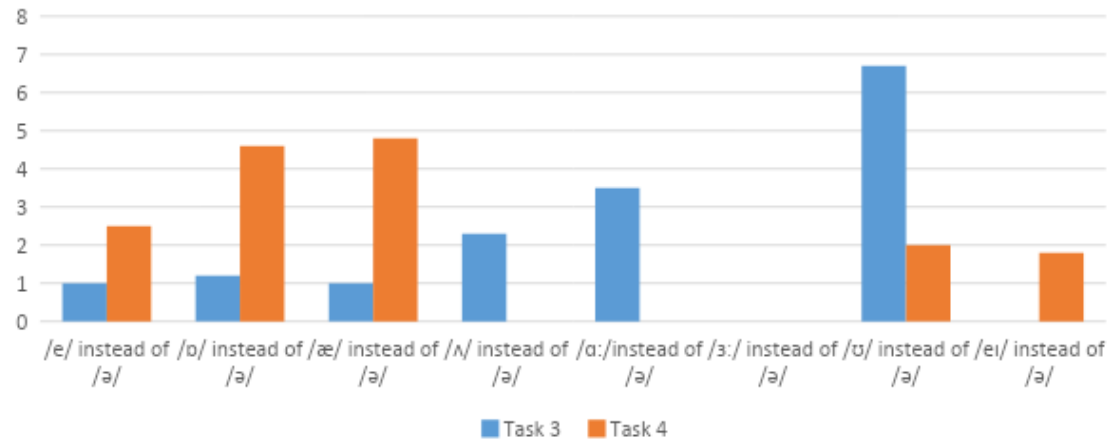

Figure 3. The distribution of types of errors associated with schwa in Tasks 3 and 4

In contrast to Task 4, the substitution of schwa for $/ v /$ is the most frequent schwa-related error in Task 3, which is made by $60 \%$ of the participants. Similarly to the substitution of schwa for /æ/, this error could be argued to reveal the participants' lack of attention to weak forms and sentence stress. Given that this type of error occurs both in SBS and GA, it could be assumed that the participants' insufficient awareness of the English stress and weak forms does not correlate with the varieties of the English language. Obviously, this finding should be treated with caution, since it is based upon the error analysis of phonemic transcriptions executed in two varieties of English, SBS and GA. Arguably, a study that involves phonemic 
transcriptions in other varieties of the Inner Circle of English (for instance, ScE, IrE, etc.) would provide results that are different from the present ones.

Another observation that is evident from the data analysis is that the standard deviation of all error types in Task $4(\mathrm{M}=8.03$; $\mathrm{SD}=3.87)$ is higher in contrast to the standard deviation in Task $3(\mathrm{M}=8.08$; $\mathrm{SD}=$ 2.87). This finding indicates that Task 4 is characterised by a noticeable variation in the total number of errors, as illustrated by Figure 4.

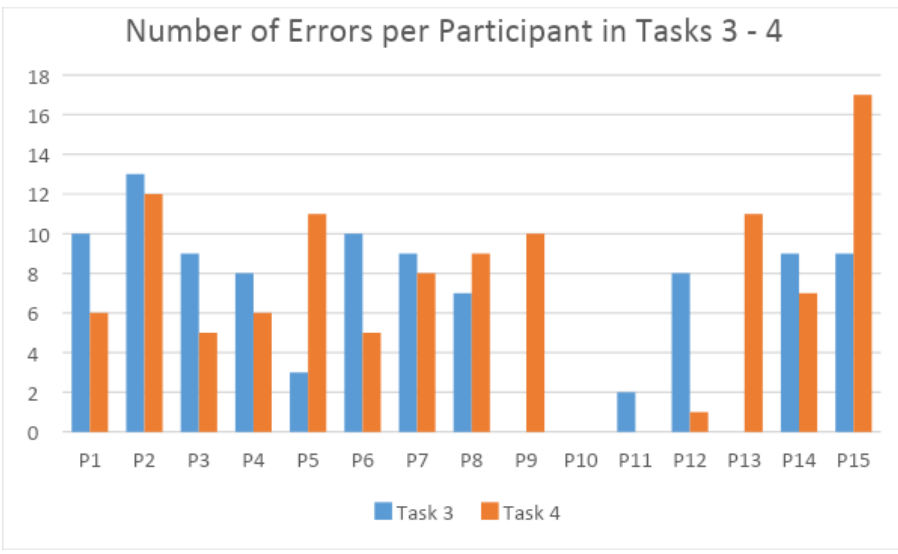

Figure 4. The number of errors per participant in Tasks $3-4$

It is seen in Figure 4 that the total number of errors per participant in Task 4 ranges from $\mathrm{N}=1$ (Participant P12) to $\mathrm{N}=17$ (Participant P15), whereas only one participant (P10) has no errors both in Tasks 3 and 4. In case of Participant's P15 spike in errors in GA, the error analysis indicates that the majority of them are associated with the transcription of the that is erroneously transcribed as /ðe/.

Another observation that is evident from Figure 4 concerns Participants P9, P13, P15 and P12, whose schwa-related errors are distributed differently from the rest of the group. In particular, whilst the schwarelated errors per group appear to be similarly distributed in Tasks 3 and 4, errors in Participants' P9, P13, and P15 transcriptions in GA are above the group mean $(\mathrm{M}=8.03)$. In contrast, however, Participant P12 makes substantially more mistakes in SBS in Task 3, whereas the participant's errors in Task 4 are below the group mean $(M=8.03)$. These findings could 
be explained by the participants' individual preferences in terms of their preferred variety of the English language. In this regard, it should be noted that Norwegian L1 EFL learners are free to choose the variety of English they speak in instructional contexts. In practice, it means that there is no institutionalised policy that mandates Norwegian EFL teachers to teach their students by means of using, for instance, SBS (Graedler 2014; Rindal and Piercy 2013). On the contrary, it is up to an individual EFL teacher to use the variety of the English language the teacher is comfortable with. Similarly, a Norwegian EFL student is not limited to using only SBS in the instructional settings. Given that Norwegian EFL students are exposed to GA via media, travel, and personal contracts (Rindal 2010), many of them use it both in intramural and out-of-classroom contexts. The current literature indicates that whereas Norwegian L1 EFL learners tend to prefer SBS at school (Rindal 2010), they exhibit preferences for GA in out-of-school contexts. Presumably, Participants' P9, P13, and P15 schwa-related errors in Task 4 are accounted by their preferred use of SBS and, consequently, insufficient use of GA. Similarly, Participant's P12 numerous schwa-related errors in Task 3 are explicable by the participant's preference for GA, given that in Task 4 this participant makes substantially fewer schwa-related mistakes (see Figure 4).

\subsection{The post-hoc procedure}

The post-hoc procedure in this study involves an oral task in English. In the second semester of study, the participants are asked to produce a spontaneous narrative of approximately five minutes in duration about their quotidian experiences. In total, 11 out of 15 participants have sent their recordings with the narratives $(\mathrm{M}$ duration $=3,7$ minutes; $\mathrm{SD}=$ 1,35 ; minimum $=1,25$ minutes; maximum $=6,4$ minutes). The narratives have been examined by the author of the article and the experienced phonetician who works at the university examination board. The results of the error analysis of the participants' oral speech in English reveal that the participants make several schwa-related mistakes. Table 6 below presents these types of errors and provides the percentage of the participants $(\mathrm{N}=$ 11) who make them. 


\begin{tabular}{|c|c|c|}
\hline $\mathbf{N}$ & Error type & $\begin{array}{c}\text { Percentage of participants } \\
\text { who make schwa-related } \\
\text { errors in speech }\end{array}$ \\
\hline 1 & /e/ instead of /ə/ & $36.4 \%$ \\
\hline 2 & $/ \mathrm{p} /$ instead of $/ \mathrm{\partial} /$ & $45.5 \%$ \\
\hline 3 & /æ/ instead of /ə/ & $63.6 \%$ \\
\hline 4 & $/ \Lambda /$ instead of $/ \partial /$ & - \\
\hline 5 & /a:/ instead of /ə/ & $36.4 \%$ \\
\hline 6 & /3:/ instead of /ə/ & - \\
\hline 7 & $/ \mho /$ instead of $/ \partial /$ & $27.3 \%$ \\
\hline 8 & /eI/instead of /ə/ & $9.0 \%$ \\
\hline
\end{tabular}

Table 6. Schwa-related errors in the post-hoc procedure

It follows from the error analysis summarised in Table 6 that schwarelated errors occur in the participants' speech in English as well as in their phonetic transcriptions in the IPA. In line with the prior literature (Łodzikowski 2021; Mompean and Fouz-González 2021; Tišma and Jeremić 2017; Trzeciakowska 2016), this finding could be taken to indicate that phonemic transcription appears to be a useful means of identifying errors in EFL learners' speech production in English. Specifically, the participants' spontaneous speech in English in the post-hoc task is characterised by eight error types associated with schwa (see Table 6).

Judging from the data, the substitutions of schwa for $/ \mathrm{p} /, / \mathfrak{x} /, / \mathrm{v} /$, and /eI/ are related to the participants' use of the full forms instead of weak ones. This finding supports the results of the error analysis of the participants' phonemic transcriptions in the IPA that are marked by the presence of similar, if not identical, schwa-related mistakes. Presumably, schwa-related errors that are manifested by the substitutions of schwa for $/ \mathrm{p} /, / \Re /, / \mho /$, and $/ \mathrm{e} /$ are reflective of the participants' lack of attention to stress in English, especially on the level of phrase and sentence.

In the post-hoc, the substitution of schwa for /e/ is typically associated with the definite article the, whereas the substitution of schwa for /a:/, to a substantial extent, occurs in the preposition about. Arguably, these types of errors could stem from the English spelling conventions and, 
perhaps, the influence of Norwegian, the participants' L1. Obviously, these assumptions are tentative, since a more substantial corpus of errors and a more representative number of participants are needed in order to ascertain the exact cause/causes of schwa-related errors in Norwegian L1 EFL learners' speech in English.

\section{Conclusions}

The study presented in this article discusses schwa-related errors in a series of phonemic transcriptions executed by the participants, who are Norwegian L1 EFL students on the intermediate level of proficiency in English. The meta-analysis of the current literature reveals that little is known to-date about whether or not intermediate EFL students whose L1 is Norwegian experience problems associated with schwa in phonemic transcriptions in the IPA. To shed light on this issue is especially topical in light of the recent publications (Kapranov 2019b) that indicate that young EFL learners in Norway encounter problems with schwa. Judging from the results of the present study, the same could be posited about Norwegian L1 EFL learners on the intermediate level of proficiency.

In line with Mompean and Fouz-González (2021), phonemic transcription is regarded in the study as a diagnostic means of identifying the participants' problems with schwa. The results of the error analysis of the participants' phonemic transcriptions reveal the presence of several types of schwa-related errors that appear to correlate with the results of the post-hoc procedure. These errors involve the substitutions of schwa for $/ \mathrm{e} /, / \mathrm{p} /, / \Re /, / \mathrm{a}: /, / \mathrm{v} /$, and /eI/. Whereas the substitutions of schwa for $/ \mathrm{p} /, / æ /, / \mho /$, and /eI/ are indicative of the participants' problems with the sentence stress English, the substitutions of schwa for /e/ and / $\square$ :/ seem to be accounted by the impact of the English orthography, which, presumably, is coupled in these cases with the negative transfer from the Norwegian language into English. To reiterate, these findings should be approached with caution, since the study involves a limited number of participants (total $\mathrm{N}=15$ ).

Whilst there are limitations in the study, it has, nevertheless, revealed a novel aspect that is associated with a potential impact of the variety of English upon schwa-related errors in the participants' phonemic transcriptions. In particular, it has been found that the impact of the variety of the English 
language, specifically, SBS and GA is not statistically significant as far as the distribution of schwa-related errors in the participants' phonemic transcriptions is concerned. In this regard, the author acknowledges that these findings should not be generalised, since, ideally, more varieties of the English language should have been tested in the study. Hopefully, the present findings could offer a promising avenue of future research.

In terms of the linguo-didactic implications of this study, the following could be summarised. First, the use of phonemic transcription in EFL instructional settings allows to identify and classify EFL learners' mistakes associated with segmental and suprasegmental properties of English, in particular, schwa-related errors. Consequently, the author argues that phonemic transcription as a useful diagnostic tool should be more amply employed in the EFL teaching and learning contexts, especially on the B1/ B2 levels of EFL proficiency. Second, the results of the study point to schwa as a problem to intermediate EFL learners whose L1 is Norwegian. Judging from the results of the study, schwa as a source of problems reflects the lack of the learners' awareness of the sentence stress that results in a series of substitutions of schwa for other English vowels. In this regard, it seems pertinent to allocate more resources towards the teaching and learning of English stress, especially on the level of phrase and sentence.

\section{Acknowledgements}

I wish to acknowledge the participants in the study whose input is invaluable. I express my gratitude to the editor and the reviewers for their comments and suggestions concerning this article. I am appreciative of the organisers and participants of the $5^{\text {th }}$ Belgrade International Meeting of English Phoneticians (BIMEP 2020), where parts of the present study were presented and discussed. 


\section{References}

Ahn, S. (1997). The Schwa Phenomenon in English Vowels. English Teaching, 52(3), 257-279.

Bardakci, M. (2015). Turkish EFL Pre-Service Teachers' Pronunciation Problems. Educational Research and Reviews, 10(16), 2370-2378.

$\mathrm{B} ø \mathrm{hn}, \mathrm{H}$. and T. Hansen (2017). Assessing Pronunciation in an EFL Context: Teachers' Orientations towards Nativeness and Intelligibility. Language Assessment Quarterly, 14(1), 54-68.

Boswell, E. (2020). "Revenge of the Schwa": A Metaphor for Teaching English Word Stress in Academic Vocabulary. In: Y. Sun, L. Li and H. Cai (eds.), Asian Research on English for Specific Purposes, Singapore: Springer, 69-83

Bryła-Cruz, A. (2021). The Gender Factor in the Perception of English Segments by Non-Native Speakers. Studies in Second Language Learning and Teaching, 11(1), 103-131.

Busby, N. L. (2021). Words from Where?: Predictors of L2 English Vocabulary among Norwegian University Students. ITL-International Journal of Applied Linguistics, 172(1), 58-84.

Carley, P. and I. M. Mees (2021). British English Phonetic Transcription. London/New York: Routledge.

Chvala, L. (2020). Teacher Ideologies of English in 21st Century Norway and New Directions for Locally Tailored ELT. System, 94, 102327.

Cruttenden, A. (2014). Gimson's Pronunciation of English. London/New York: Routledge.

Čubrović, B. (2007). What's in a Symbol? The Case of HappY and Thank YOU Vowels and the Serbian EFL Learner. In: PTLC Phonetics Teaching \& Learning Conference August, London: UCL, 1-4.

Čubrović, B. and A. Bjelaković (2020). Standard Southern British as a Pronunciation Model in the Serbian EFL Classroom. In: Penda, P., Ž. Babić and T. Bijelić (eds.), Beyond Hermeneutics. Challenging Traditional Approaching to Literary and Linguistic Studies, Banja Luka: University of Banja Luka, 99-110.

Demirezen, M. (2021). The Phonological and Morphological Foundations of the Secondary Stress Phoneme in North American English: Article Type: Compilation. Eurasian Journal of Language Teaching and Linguistic Studies, 1(1), 1-13. 
Flemming, E. (2009). The Phonetics of Schwa Vowels. In: Minova, D. (ed.), Phonological weakness in English, Houndsville: Palgrave Macmillan, 78-95.

Fornacciari P., B. Guidi, M. Mordonini, J. Orlandini, L. Sani and M. Tomaiuolo (2017). Guess the Movie - Linking Facebook Pages to IMDb Movies. In: Guidotti, R. Monreale A., Pedreschi D., and Abiteboul S. (eds.), Personal Analytics and Privacy. An Individual and Collective Perspective. PAP 2017. Lecture Notes in Computer Science, vol 10708, Cham: Springer. (1 August 2021) <https://doi.org/10.1007/978-3319-71970-2_9>.

Goldstein, J., G. M. Ciany and J. G. Carbonell (2007). Genre Identification and Goal-Focused Summarization. In: Proceedings of the sixteenth ACM conference on Conference on information and knowledge management, CIKM '07, New York: ACM, 889-892.

Graedler, A.-L. (2014). Attitudes towards English in Norway: A CorpusBased Study of Attitudinal Expressions in Newspaper Discourse. Multilingua, 33(3-4), 291-312.

Heselwood, B. (2007). Schwa and the Phonotactics of RP English. Transactions of the Philological Society, 105(2), 148-187.

Heselwood, B. (2006). Final Schwa and R-sandhi in RP English. Leeds Working Papers in Linguistics and Phonetics, 11, 78-95.

Hickey, R. (2007). Irish English. History and Present-day Forms. Cambridge: Cambridge University Press.

Hida, K. (2020). The Effectiveness of Shadowing in English Weak Vowels Acquisition: A Study of Japanese Junior High School Students. Dialogue, 18, 1-20.

Hiss, F., A. M. Pesch and H. Sollid (2021). Multilingual Encounters in Northern Norway. Acta Borealia, 38(1), 1-4.

Hunt, K. (1965). Grammatical Structures Written at Three Grade Levels (NCTE Research Rep. No. 3). Champaign, IL: National Council of Teachers of English.

Hunt-Gómez, C. I. and M. Navarro-Pablo (2020). Analysis of Pre-Service Foreign Language Teachers' Incorrect Articulations: Frequency, Influence on Communication, and a Specific Corrective Strategy. Problems of Education in the 21st Century, 78(6), 933-947.

IBM (2011). IBM SPSS statistics for Windows, version 20.0. New York: IBM Corp.

Jenkins, J. (2004). Research in Teaching Pronunciation and Intonation. Annual Review of Applied Linguistics, 24(1), 109-125. 
Jurida, H. S. (2014). From Introduction to Phonemic Symbols to Development of Transcription Skills: A Case Study in the English Department at University of Tuzla. Explorations in English Language and Linguistics, 2(2), 116-132.

Kapranov, O. (2019a). In-Service Primary School Teachers' Account of Phonetically Difficult Words in English as a Foreign Language. Research in Language, 17(3), 297-315.

Kapranov, O. (2019b). Self-Assessment of the Sounds of the English Language that Pre-Service EFL Teachers Consider Problematic to Pronounce. ELOPE: English Language Overseas Perspectives and Enquiries, 16(1): 77-99.

Kapranov, O. (2019c). The Framing of a Preferred Variety of English by Pre-Service Primary School Teachers of English as a Foreign Language. ANGLICA - An International Journal of English Studies, 28(2), 117-139.

Lacabex, E. G., M. L. G. Lecumberri and M. Cooke (2008). Identification of the Contrast Full Vowel-Schwa: Training Effects and Generalization to a New Perceptual Context. Ilha do Desterro: A Journal of English Language, Literatures in English and Cultural Studies, 55, 173-196.

Lee, Y. (2020). The Effectiveness of Explicit Form-Focused Instruction in Teaching the Schwa /o/. The Journal of the Korea Contents Association, 20(8), 101-113.

Levis, J. M. (2018). Intelligibility, Oral Communication, and the Teaching of Pronunciation. Cambridge University Press.

Lintunen, P. (2013). The Effect of Phonetic Knowledge on Evaluated Pronunciation Problems. In: Przedlacka, J., J. A. Maidment, and M. Ashby (eds.), Proceedings of the Phonetics Teaching and Learning Conference, London: UCL, 55-58.

Lintunen, P. (2005). Phonemic Transcription and its Effect on Learning. In: Maidment,J. A. (ed.), Proceedings of the Phonetics Teaching and Learning Conference, London: UCL, 1-4.

Łodzikowski, K. (2021). Association between Allophonic Transcription Tool Use and Phonological Awareness Level. Language Learning \& Technology, 25(1), 20-30.

Maguire, W. (2018). The Origins of Epenthesis in Liquid+Sonorant Clusters in Mid-Ulster English. Transactions of the Philological Society, 116(3), 484-508.

Makino, T. (2009). Vowel Substitution Patterns in Japanese Speakers' English. In: Čubrović, B. and T. Paunović (eds.), Ta(l)king English 
Phonetics Across Frontiers, Newcastle: Cambridge Scholars Publishing, 19-31.

Minkova, D. and M. Lefkowitz (2021). Middle English Open Syllable Lengthening (MEOSL) or Middle English Compensatory Lengthening (MECL)?. English Language \& Linguistics, 25(1), 155-180.

Mompean, J.A. (2017). Doing Phonetic Transcription in a Modern Language Degree. In: Espinosa, J. A. C., J. M. H. Campoy, R. M. M. Ruiz, and F. M. Martínez (eds.), Estudios de filología inglesa: Homenaje al profesor Rafael Monroy, Murcia: EditUM, 479-505.

Mompean, J. A. (2005). Taking Advantage of Phonetic Symbols in the Foreign Language Classroom. In: Maidment,J. A. (ed.), PTLC05: Proceedings of the Phonetics Teachingand Learning Conference, London: UCL, 1-4.

Mompean, J. A. and J. Fouz-González (2021). Phonetic Symbols in Contemporary Pronunciation Instruction. RELC Journal, 52(1), 155-168.

Mompean, J. A. and P. Lintunen (2015). Phonetic Notation in Foreign Language Teaching and Learning: Potential Advantages and Learners' Views. Research in Language, 13(3), 292-314.

Monroy-Casas, R. (2011). Systems for the Phonetic Transcription of English. Theory and Texts. Frankfurt-am-Main: Peter Lang.

Nilsen, T. S. and K. P. N. Rugesæter (2015). English Phonetics for Teachers. Third Edition. Bergen: Fagbokforlaget.

Pennington, M. C. (2021). Teaching Pronunciation: The State of the Art 2021. RELC Journal, 51(1), 3-21.

Pennington, M. C. (2014). Phonology in English language teaching: An international approach. Routledge.

Rahal, A. (2016). The Fossilized Pronunciation of the Schwa Sound/ə/ in the Speech of Advanced Tunisian English Learners: Problem and Causes. International Journal of Humanities and Cultural Studies, 1(1), 55-60.

Recasens, D. (2021). Acoustic Characteristics and Placement within Vowel Space of Full Schwa in the World's Languages: A survey. Journal of the International Phonetic Association, 1-36. doi:10.1017/ S0025100320000122

Rehman, I., A. Silpachai, J. Levis, G. Zhao and R. Gutierrez-Osuna (2020). The English Pronunciation of Arabic Speakers: A Data-Driven Approach to Segmental Error Identification. Language Teaching Research, 1-27. 
Rindal, U. (2010). Constructing Identity with L2: Pronunciation and Attitudes among Norwegian Learners of English. Journal of Sociolinguistics,14(2), 240-261.

Rindal, U. and C. Piercy (2013). Being 'Neutral'? English Pronunciation among Norwegian Learners. World Englishes, 32(2), 211-229.

Rugesæter, K. P. N. (2014). Difficult Contrasts: An Analysis of Phonemic Distinctions in the English of Young Norwegian Learners Seen against the Backdrop of Incidental Foreign Language Learning. Acta Didactica Norge - tidsskrift for fagdidaktisk forsknings og utviklingsarbeid i Norge, $8(1), 1-20$.

Silverman, D. (2011). Schwa. In: van Oostendorp, M., C. J. Ewen, E. Hume and K. Rice (eds.), The Blackwell Companion to Phonology, Malden, MA: Wiley-Blackwell, 628-642.

Smith, B. (2012). Pronunciation Patterns of Japanese Learners and their Implications for Teaching. Polyglossia, 23, 199 - 206.

The Council of Europe (2011). Common European Framework of Reference for Languages: Learning, Teaching, Assessment. (1 August 2021) <https://www.coe.int/en/web/language-policy/home?e1_en.asp>.

Tišma, D. J. and J.D. Jeremić (2017). A Novel Approach to Teaching the IPA Chart and Phonemic Transcription: Insights and Implications. Philologia Mediana, 9(9), 587-606.

Trzeciakowska, J. (2016). Mistakes in phonemic transcriptions made by Polish EFL Teacher Training College students. Currents: A Journal of Young English Philology Thought and Review, 2, 162-183. (1 August 2021) <http://www.currents.umk.pl/files/issues/CURRENTS-NO.-2.pdf > .

Udir (2021). Læreplan i engelsk (ENG1-03). (1 August 2021) <https:// www.udir.no/kl06/ENG1-02/Hele/Hovedomraader/?lplang=eng $>$.

Underhill, A. (2005). Sound Foundations: Learning and Teaching Pronunciation. Oxford: Macmillan Education.

Vattøy, K.-D. (2019). Learning English in Norway. Language Issues: The ESOL Journal, 30(2), 79-81.

Visoni, Y. and L. Marlina (2020). Students' Pronunciation Errors on Vowels at Spoken English Activities (Speech) Class at English Department Universitas Negeri Padang. Journal of English Language Teaching, 9(3), 488-494.

Vishnevskaya, G. M. (2011). Pronunciation Error Variables in ESP: The Case of Russian English. In: Tyurina, S. (ed.), Традиции и новаторство 
в преподавании родного и иностранного языков в вузе, Ivanovo: Ivanovo University Press, 78-81.

Wells, J. C. (1996). Why Phonetic Transcription is Important. Malsori, 31$32,239-242$.

Wheelock, A. (2016). Phonological Difficulties Encountered by Italian Learners of English: An Error Analysis. Hawaii Pacific University TESOL Working Paper Series, 14, 41-61.

Received: 02 August 2021

Accepted for publication: 02 September 2021 